\title{
Sex Trafficking in Nepal: Context and Process.
}

\section{OPPORTUNITIES AND CHOICES WORKING PAPER \\ No. 11 April 2004.}

Dr. Monique Hennink

Senior Research Fellow

Opportunities and Choices Reproductive Health Research Program

Division of Social Statistics

University of Southampton

Southampton

UK, S017 1BJ

Tel: +44-2380-597989

Fax: +44-2380-593846

Email: mon@socsci.soton.ac.uk

Dr. Padam Simkhada

Research Fellow

Department of Public Health, University of Aberdeen

Medical School, Polwarth Building

Foresterhill, Aberdeen AB25 2ZD

Scotland, UK

Tel: +44-1224-552492

Fax: +44-1224-550925

Email: p.p.simkhada@abdn.ac.uk 


\title{
Sex Trafficking in Nepal: Context and Process.
}

\begin{abstract}
This study has developed a conceptual framework to provide a clearer understanding of the process and context of sex trafficking from Nepal. Quantitative data were analysed from case records of 202 sex-trafficked women at rehabilitation centres in Nepal. In-depth interviews with 42 sex trafficked women, mostly residing at rehabilitation centres in Kathmandu, provide contextual information on the process and circumstances of sex trafficking. The results of this study provide a clearer understanding of the stages of movement through the sex trafficking process; in particular that sex trafficking does not always begin at the village level, it may also occur after voluntary migration or after trafficking to urban areas for other purposes (ie: labour exploitation). Interventions therefore need to target each stage of movement through sex trafficking. Respondents were most commonly sex trafficked by familiar persons, including relatives (68\%); and force and abduction are less common (6.8\%). Women exited from sex-trafficking through rescue, escape or release. One of the outcomes of sex trafficking is a return to sex work upon return to Nepal.
\end{abstract}

Keywords: Sex-Trafficking, Migration, Nepal, Sex Work, Young People, Stigma. 


\section{Introduction}

Many women who become involved in sex work in Asia do so because they are compelled by economic circumstances and social inequality. While some enter sex work voluntarily, others become involved in sex work by force or deception, such as through sex trafficking. The United Nations Protocol on Trafficking in Persons (2000), signed by 80 countries, officially recognizes all types of human trafficking, including sex trafficking, as a modern form of slavery and forced labour that relies on coercion, fraud or abduction in order to flourish. The United Nations defines human trafficking as:

“...the recruitment, transportation, transfer, harbouring or receipt of persons, by means of threat or use of force or other forms of coercion, of abduction, of fraud, of deception, of the abuse of power or of a position of vulnerability or of giving or receiving of payments or benefits to achieve the consent of a person having control over another person for the purposes of exploitation. Exploitation shall include, at a minimum, the exploitation or the prostitution of others or other forms of sexual exploitation, forced labour or services, slavery or practices similar to slavery, servitude or the removal of organs." (United Nations 2000:3).

While the UN protocol defines trafficking for a number of purposes (ie: forced labour, slavery, removal or organs), it is the trafficking of women and girls for sexual exploitation, or sex trafficking, which is the focus of this paper. Sex trafficking often involves migration either within nations or across national borders; however, the boundaries between migration and sex trafficking are often unclear, because an activity may not be recognisable as sex trafficking until the destination is reached and the deception is revealed. Until then a journey may be indistinguishable from voluntary migration (Huntington 2002). In addition, some women and girls may be sex trafficked after voluntary economic migration to urban areas, or they may have been trafficked for one purpose (eg: employment, servitude) and later sex trafficked. 
Globally, it is estimated that between 700,000 (U.S. Department of State, 2001) and four million (UNFPA, 2000) people are trafficked each year, for all purposes. The large differential in these estimated figures reflects the difficulty in obtaining accurate data on this phenomenon. There is no accurate figure of the scale of sex trafficking of women and girls from Nepal. Despite published figures suggesting that between 5,000 to 7,000 Nepali women and girls are trafficked for sex work each year, and that 200,000 Nepali women and girls are working in the sex industry in India (Human Rights Watch 1995:6), the actual magnitude of women and girls who are sex trafficked from Nepal is unknown (ODea 1993; Rozario and Rita 1988). Even these figures are speculative and based on observations and anecdotal information rather than scientific evidence; partly a reflection of the clandestine and illegal nature of sex trafficking.

The issue of trafficking in Nepal needs to be viewed from a broader context which recognises socio-cultural structures, gender roles, in particular gendered power differentials, and the role of poverty. These influences underlie the migration process in Nepal and increase the vulnerability of young women and girls to trafficking and sexual abuse. Nepal is a country with one of the lowest human development indicators in the world, and is ranked at 143 on the United Nations Human Development Index. Life expectancy at birth is 59 years, adult literacy is $42 \%$, infant mortality (66/1000 live births) and maternal mortality (540/100,000 live births) are amongst the highest in the world (UNDP 2003). A large proportion of the population live below the poverty line, with $38 \%$ of the population living on US\$1 per day and $82 \%$ on US $\$ 2$ per day (UNDP 2003). Nepal is a predominantly agrarian nation, with $90 \%$ of the population relying on subsistence agriculture. However, the traditional subsistence economy is no longer an economically viable means of livelihood and this has led to a tradition of labour migration from rural areas. Both women and men migrate to seek sustainable livelihoods elsewhere, often outside Nepal (WOREC/CEDPA 1999), and the level of migration amongst those of prime productive ages is escalating (Sanghera 2000; Gushulak 
and MacPherson 2000). The extent to which migration in Nepal involves women is unclear. Seddon et al (1999) report that $23 \%$ of registered migrants were women, but suggest that the actual figure may be much higher as much female migration is often unrecorded due to the concentration of female labour in the informal, unregulated economic sectors. Migration of women is also shown to be higher amongst poorer households (de Haan 2000). Labour migration is becoming an important part of the social structure in Nepal, and the remittances from this process form a vital part of household income for rural economies. The $1996 \mathrm{Nepal}$ National Living Standards Survey estimates that $24 \%$ of rural households in Nepal receive remittances, mostly from other places in Nepal and from India, accounting for $25 \%$ of their household income (Seddon et al 1999). Rural poverty is thus a significant factor in the migration process in Nepal, leading to the movement of men and women to seek sustainable employment elsewhere. Studies have shown that children, particularly those not in school, share a major portion of the household work burden. Girls aged between six to nine years are shown to contribute 7 hours to household duties and those aged 10-14, 9.5 hours (RIDA 1991). Due to economic necessity children are also increasingly sent to urban areas for employment to supplement family incomes. Girls may be sent to work in urban carpet factories or in the homes and fields of creditors (UNICEF 1996). Although migration is distinct from trafficking, as migration increases more people may be trafficked in the process (O’Dea 1993; Acharya 1998; ILO/IPEC 1998; ABC Nepal 1996). Both trafficking and migration operate predominantly through personal connections and social networks or through brokers who may or may not be strangers to the community. Women and girls may be attracted by reports of high incomes and the glamour of life in urban areas, and be easily deceived by mediators. Trafficking for sexual exploitation is also interlinked with trafficking for other purposes, for example, it is not uncommon for trafficking to take part in stages whereby women and girls are first trafficked for labour exploitation and later sex trafficked (Asia Foundation/Population Council 2001). Hence the process of sex trafficking cannot be viewed in isolation from trafficking for other purposes or from the process of migration. 
The traditionally patriarchal society in Nepal means that women are largely confined to domestic environments and duties. Their access to knowledge, skills, resources, opportunities and power remain low (UNICEF 1996; Shtrishakti 1995; Acharya and Bennett 1981). Enrolment of girls in primary school is $61 \%$, while that of boys is $80 \%$. The adult literacy rate further reflects disparities in education, with $23 \%$ of adult women literate compared with 57\% of men (UNICEF 1996). Early age at marriage and consequent movement to reside with the husband's family also obstructs girls' secondary education. Nepal has a high incidence of son preference (Leone et al 2003; RIDA 1991), as sons provide economic insurance for parents; daughters will marry and care for their husband's family and so investments in their future are less valued (UNICEF 1996). Women in Nepal have low status within the family and males enjoy the primary rights over paternal inheritance. Property will automatically pass through the male lineage, and once married a daughter holds no inheritance rights as long as her brothers or sons of brothers are alive (HMG/Nepal 1990). Early marriage in Nepal is common; the average of marriage for girls is 16.6 years (Ministry of Health et al 2002). Marriage is typically arranged by a girls' parents in negotiation with the groom's family and girls are given little autonomy in this process.

The determinants of female trafficking are complex and multi-causal. At an individual level, trafficking is thought to be enabled by the existence of gender discrimination and unequal power relations favouring males, in addition lower female education, poverty and lack of economic opportunities all play a role in trafficking (Poudel and Carryer 2000; Acharya 1998; ILO/IPEC 1998; ABC Nepal 1996; O’Dea 1993). These local level processes are also shaped by macro-economic changes that influence migration and shifts in employment demands towards labour intensive manufacturing for exports which favour female labour and influence migration (de Haan 2000). 
Trafficking of young women and girls has been recognised as a particular problem in Nepal, which is viewed as one of the 'sending' countries in the Asian network of trafficking, and India and Pakistan are typical 'transit' or 'destination' countries for all types of trafficking, particularly sex trafficking. Increasing concern about the trafficking of women and girls has spurred the Government of Nepal to develop several national policies to address trafficking. In 1986 the Traffic in Humans (Control) Act was passed, which focuses largely on trafficking for the purpose of prostitution. However, the policy was largely ineffective due to the lack of political and judicial will to enforce the Act and the lengthy and complex prosecution procedures. It is considered one of the most poorly enforced acts in Nepal (CeLRRd 2000). In addition, this act is largely aimed at criminalising prostitution rather than curbing trafficking activities (Asia Foundation/Population Council 2001). Since the early 1990s trafficking has been identified as a priority issue in Nepal and many non-government organisations (NGOs), community-based organisations and Government Ministries have developed social, cultural, and economic programs to address the problems of trafficking. The international donor community increased funding for related social issues, including welfare issues of women and children, bonded labour and human rights. In 1998, the Government of Nepal established the Ministry of Women, Children and Social Welfare, which worked in conjunction with the International Programme on the Elimination of Child Labour and the International Labour Organisation to develop a comprehensive thirteen-point strategy for the prevention of trafficking. At the National level these strategies include; developing a National Coordination Committee for the prevention of trafficking women and girls; launching awareness campaigns on trafficking; introducing educational and employment oriented programmes for women and girls; introducing HIV/AIDS awareness programmes; and working to increase political commitment, and encouraging integrated programmes between Government and NGOs working towards prevention of trafficking. At the local level the strategies include; developing local co-ordinating committees and information centres on trafficking; and boosting local employment generation for poverty alleviation (Khatri 2002). Despite the development of these strategies, there has been more recent criticism of national and local 
level political apathy on the issue, and the continued chronic lack of law enforcement to address this problem. While the government has expressed a commitment towards antitrafficking activities, most initiatives remain at the planning stages or await funding (UNDP 1999). In 1999 Nepal was identified by the Office of the High Commissioner for Human Rights Trafficking Program as one of the key countries in urgent need of intervention (Asia Foundation/Population Council 2001).

There is a dearth of quantitative data on the characteristics of sex trafficked women, partly due to its illegal nature and the difficulties in contacting women and girls who have been trafficked for sex work. There also exists a lack of scientific research investigating the context of sex trafficking from Nepal. Much existing information about sex trafficking in Nepal is collated in NGO publications (for example Pradhan 1996; Human Rights Watch 1995; ABC Nepal 1996, 1998; Ghimire 2001), which present anecdotal case studies, newspaper reports and commentary from agencies working to prevent sex trafficking. There exist a limited number of unpublished reports on trafficking in the South Asia region (Huntington 2002; Poudyal 1996; Khatri 2002), which include some information on sex trafficking; however these largely focus on policy analysis rather than the results of empirical research. No scientific, empirical research has been published using data from sex trafficked women themselves, which investigates the nature and process of sex trafficking in Nepal; the spatial context of sex trafficking; and the complex issues surrounding community reintegration upon return to Nepal. Comprehensive research is urgently needed to further understand the process of sex trafficking and to further support the development of effective, comprehensive and feasible anti sex trafficking measures within Nepal. This paper contributes to a currently understudied area of socio-demographic research in Nepal.

The overall objective of this study is to provide a better understanding of the process and context of sex trafficking of young women and girls from Nepal to India. The more specific 
aims are to investigate; a) the characteristics of sex trafficked women and girls; b) the routes of entry and exit from sex trafficking; and c) strategies for reducing the risk of sex trafficking to women and girls.

\section{Methods}

Young women and girls who have been trafficked for sex work are a hidden population, largely due to the illegal nature of sex trafficking and (often under-age) sex work. Employers of sex trafficked women and girls may keep them hidden from public view and limit their contacts with outsiders. Women and girls who have been sex trafficked may not identify themselves as such through fear of reprisals from their employers; fear of social stigma from involvement in sex work or their HIV positive status; and shame of their activities being revealed to family members. Therefore, identifying sex trafficked women and girls and obtaining access to them for interview is highly unlikely. It is only once these individuals have left their trafficked situation that they may be identified through contact with health workers, judicial institutions, NGOs and aid organisations. Any interview with sex trafficked women and girls is therefore likely to be a 'post-trafficking' contact, such as accessing formerly sex trafficked women and girls in transit homes, rehabilitation centres or in their communities of origin after return. In view of these difficulties, the target population for this research were women and girls who had been sex trafficked to India and have subsequently returned to Nepal.

This study uses a combination of qualitative interviews and quantitative case records to identify the process, context and experiences of sex trafficking. The first stage of data collection involved conducting in-depth interviews with eight key informants, in order to provide a broader understanding of the health and social issues surrounding sex trafficking in Nepal. These included directors of non-government organisations working on sex trafficking issues, co-ordinators of rehabilitation centres for sex trafficked women and health workers 
whose clientele include former sex trafficked women. Secondly, quantitative data from case records of 202 returned sex trafficked women and girls were collated from all six rehabilitation centres in Kathmandu. These rehabilitation centres are operated by NGOs and provide welfare assistance to former sex trafficked women and girls. All centres collect the same socio-demographic information, as well as basic information about the trafficking event (ie: age, circumstances of trafficking). These case records cover the 5 year period since the establishment of all six centres, 1996-2001. All case records of sex trafficked women and girls from each centre are included in this study.

The second stage of data collection involved conducting in-depth interviews with 42 women and girls who were trafficked to India for sex work and had since returned to Nepal. A qualitative approach was most appropriate given the exploratory nature of this research amongst an understudied population sub-group. Qualitative interviewing is also appropriate for eliciting contextual, descriptive and process-oriented information and for allowing respondents to identify issues from their own perspectives. The sensitive, and sometimes illegal, nature of the research topic also required a careful interpersonal approach whereby good rapport and trust is developed between the interviewer and respondent. Respondents were identified through several methods. Thirty respondents were identified at rehabilitation centres identified above. All sex trafficked individuals currently living at these centres were invited to participate in an interview. Respondents were assured of confidentiality; in particular that information would not be shared with the rehabilitation centre. Respondents were asked about their preferred location for the discussion, some were conducted within the centre and others in nearby cafes. It was also important to collect information from sex trafficked girls and women who were no longer at a rehabilitation centre or had not passed through such centres. Twelve interviews were conducted with sex trafficked women and girls in the community. These respondents were identified through 'snowballing', which uses 
social networks to identify new respondents from those already interviewed. Snowball recruitment was particularly useful to identify sex trafficked women/girls who could not be recruited through services, such as sex trafficked women/girls now working as sex workers in Nepal and those who had returned to their home communities. These respondents were interviewed at a location of their choice, often their home or a restaurant.

The in-depth interview included discussion on the following topics; family background; process and experience of trafficking; work and conditions in Indian brothels; health issues; process of return to Nepal and expectations for the future. All interviews were conducted in Nepali by researchers with a health background. Respondents were asked of their preference for a male or female interviewer; 20 preferred to speak with the male interviewer. No women or girls refused to participate in an interview, and interviews were tape recorded and fully transcribed. Two respondents preferred the discussion was not tape recorded and information was collected through detailed notes. All interviews were conducted in 2000-2001. The textual data were analysed using thematic analysis, which involves identifying issues, experiences and processes from individual interviews. Themes are then analysed across the whole data set to build a comprehensive picture of collective experience (Benner 1985; Leininger 1985; Taylor and Bogdan 1984). Common themes contribute to describing or explaining typical processes and behaviour. Verbatim quotations from respondents are used to illustrate key processes or to describe patterns of behaviour.

An important limitation of this study is the necessity to focus on sex trafficked women and girls who had returned to Nepal; many respondents were currently or previously resident at rehabilitation centres in Kathmandu. Those sex trafficked women who have passed through a rehabilitation centre may represent a sub-set of the total population of sex trafficked women, for example those who return to Nepal as a result of police raids on Indian brothels and hence 
bear particular characteristics (ie: young age). There exists no information on the population of sex trafficked woman as a whole, so this limitations cannot be verified, however, the specific nature of this target population must be highlighted as it may influence the pattern of results found in this study.

\section{Results}

\section{Characteristics of Sex Trafficked Women/Girls}

The socio-demographic characteristics of sex trafficked women and girls who pass through a rehabilitation centre in Kathmandu are show in Table 1. These women and girls are typically unmarried, non-literate and very young at the time of trafficking. The majority were within the narrow age range of 13 to 18 years when trafficked; one third were sex trafficked when aged below 16 years and almost half were between 16 and 18 years. The youngest age at sex trafficking was 12 years and no women or girls were sex trafficked older than 25 years. Although the majority of women and girls were unmarried (60\%) at the time of trafficking, more than one third were married when sex trafficked. The young age at trafficking is likely reflective of the data source in that women at rehabilitation centres are often rescued from Indian brothels as a result of police raids on underage propitiation. Women and girls who were sex trafficked when under 16 years are twice as likely to be unmarried (45\%) than married $(21 \%)$. The predominant ethnic group of sex trafficked women and girls was Mongoloid or Dalit (untouchable), however, they originated from 25 different ethnic groups.

Figure 1 shows the districts of origin of sex trafficked women and girls who had passed through a rehabilitation centre. The distribution shows that women and girls originated from 37 districts, most of which are in the Hill or Terai ecological zones. Half of the sex trafficked women and girls originate from eight districts which are predominantly border districts in both the Western and Eastern Region or districts in close proximity to Kathmandu in the Central Region. The highest proportion of sex trafficked women and girls in this study originated from Chitwan (12\%) and Sindhpalchok (11\%) districts. Chitwan district is worthy 
of note as this is a border district which encompasses the major transport routes both from Kathmandu and the Western districts to India, making it a strategic district for sex trafficking.

\section{Routes into Sex Trafficking}

Four key routes into sex trafficking were identified and are shown in the conceptual framework (Figure 2), these include; a) employment-induced trafficking via a dalal ('broker'), b) independent migration to urban areas, c) deception, through false marriage or visits and, d) force, through abduction. These routes into sex trafficking are interlinked with independent migration and with trafficking for other purposes, notably for labour exploitation. For example, the movement of women and girls may begin with employment migration to urban areas, and after this they become sex trafficked; or trafficking is conducted in a twostage process where by women and girls are first trafficked for employment and later sex trafficked.

Young women and girls in this study entered sex trafficking either directly or indirectly. Those who became part of sex trafficking through indirect routes typically migrated from rural villages to urban areas for employment, often to work as cheap labour in carpet factories, and were then sex trafficked from these factories. Others first become trafficked for labour exploitation, typically through a dalal ('broker' or 'agent'), and then experience a second stage, sex trafficking. Carpet factories in Nepal are important recruitment centres for sex traffickers. Typically young women and girls are trafficked to urban areas to work in a carpet factory; they are then sold to a factory by a dalal and used as bonded labour until their transport to an Indian brothel can be arranged. Table 2 shows that promises of employment by a dalal ('broker') is by far the most common process of trafficking which later leads to sex trafficking, with more than half of the women/girls in this study entering in this way. An example of employment-induced trafficking is below, after which the girl was sex trafficked; 
When a lady (a dalal) who rented a house nearby told me that she could give me a good, well paid job in a carpet factory, I eagerly agreed to go with her. I left early in the morning with the woman and we went to the Kathmandu carpet factory - I was just 15.

The in-depth interviews revealed that women and girls also migrated independently or with their family to seek employment in urban areas and it was after this process that they were sex trafficked. They typically found employment in factories and were then offered better paid employment elsewhere or asked to travel on errands with dalals, which typically led to travelling to the Indian border and being sold into sex work. Dalals also operated from within factories to offer false friendship and encouragement for travel, these dalals then sold the women/girls for sex work in India. It is the younger, unmarried women and girls who are most likely to enter sex trafficking via indirect routes such as initial offers of employment or marriage by a dalal. The extracts below illustrate the indirect routes to sex trafficking through initial employment in carpet factories, after which they were sex trafficked.

My two brothers earned their own living...I thought "If boys can work, why can't girls?" "Of course I can earn my own living; I shouldn't have to depend on my parents". So I asked my mother if it would be alright if I went to Kathmandu to find a job. My mother agreed to this idea, although she knew that she would miss me when I went away. In the city I hunted for some sort of job in shops and hotels but no one wanted to employ a village girl with little education. Eventually I managed to find a job working in a carpet factory.

Tara was taken to Kathmandu when she was twelve years old to work in a carpet factory, where she worked for five years. ".........I met Hari while I was working in the factory and we became very close to each other. He told me that he would get me a good job. When he mentioned that I could earn a lot more money I instantly agreed 
to go with him. I went with him. After 3 days we reached a big hotel in a new city.

"Why am I here," I asked. "You are going to do some cooking and cleaning work," he replied. A little while later they told that I had been sold by the man".

...One day I heard that there was another factory near by, which paid higher wages than the factory I was currently working at. So I went to the other factory to ask them if they had a job for me. "You're in luck," said the manager. "I need someone to accompany me and my wife to Hetauda (another city) to collect wools for weaving. It will pay very well." I immediately agreed and took this job. I did not think anything strange about it, especially since I would be travelling with his young wife. After a long journey I found myself in Bombay. Later I found that I was sold for Rs40,000 by the manager.

Direct routes into sex trafficking were the result of deception and force, whereby women and girls were deceived into fraudulent marriages or false visits for which travel out of the village was necessary or they were abducted and sex trafficked directly to India. Those aged over 16 years are more likely than younger women and girls to have entered sex trafficking through such direct routes. In some cases traffickers conduct a fraudulent marriage ceremony and subsequently take the 'bride' to settle in India, or traffickers pose as marriage brokers for businessmen in India and convince young women to travel for marriage. Alternatively young women and girls are offered the chance to visit India for employment as housemaids, actresses or to establish a small business. Dalals often posed as potential boyfriends to gain the trust of the young women and girls before offering marriage or visits to India. Abduction was a less commonly reported entry into sex trafficking (Table 2). Most often women and girls who are abducted are drugged before a journey after which they are sold to brothel owners in India. These direct routes to sex trafficking are illustrated below. 


\section{False Marriage:}

One day I eloped with him (the dalal). He brought me to the bus park and explained that he would take me to his aunt's house in another district for a few days. On the way he offered me a bottle of coke. After drinking it I felt sleepy and woke up in a train that soon reached Delhi...

On the day of Shivaratri (Hindu festival) I went to the River to light a candle, where I met one of my relatives who was with a few men. My relative introduced me to one of the men and asked me if I would marry him. I did not take the offer seriously, besides I hardly knew that man. But my relative kept insisting. "Come on," she replied me. "At least think about it. He lives in Hetauda (another city) and is a great person. I did think about it and the idea of remarrying gave me hope that perhaps happy days would come again. I agreed and I went with him. He took me to an Indian restaurant and after this I cannot remember anything else. When I awoke I found myself in the world of brothels. I had been sold for Rs 30,000.

False Visits:

...At the age of 15, I went with a friend to watch a movie and met a young man with whom I became friendly. After some time he suggested going to a bigger southern town to buy cheap cloth with which to start my own small business. I went with him without asking my parents. Instead, he took me to India.

One day, my friend Sita, her husband and myself went to watch the movies together. After the film they asked me if I would go to India with them. I could not refuse their request, as I was interested to be an actress and I also felt indebted to them for always welcoming me into their house. We caught a train and spent three days travelling. Eventually we reached our destination- Bombay. At first we stayed at a hotel but were soon taken to another place where the women were decorated with 
expensive jewellery, clothes and scents. There we met a fat lady who was introduced to us as film director. She seemed very kind and generous and we were impressed. Sita's husband told the "film director" to let us rest and said that he would come back after he had been shopping. He never returned. We were told that it was a brothel and the lady was gharwali (brothel owner). We had been sold for Rs 60,000 by the man.

\section{Abduction:}

Dilmaya was taken to India by neighbours whom she knew quite well. They told her that they had to go to a market far from their village to pick up something and asked her to come along. Dilmaya often went places with them, but usually they travelled by bus. That day there was a taxi waiting for them. They travelled a long way, and it was very late when they finally arrived in Badi Bazaar. They got in another taxi and arrived at a house where she was put in a room and the door was locked. Dilmaya had no idea where she was. A woman told her that the lady she came with had gone out and would be back later, but she never came back. After several days they travelled to another town when Dilmaya pleaded to let her go, she was told "No, you have been sold and have to work. All Nepali girls have to work."

In addition to the direct routes to sex trafficking described above, a dalal may also directly approach families in villages who are in desperate economic situations and are willing to let their daughters travel with a dalal in exchange for a fee. Often it is believed that women and girls would be working in domestic employment. In these circumstances parents are often completely ignorant of the dalal's true intentions or their poverty is such that they do not question the offer. For example:

One couple came to our village for Dashain (Nepali festival). In the last day of festival they came to our house and talked with my father and mother, they need a girl to look after their three year old child. My father agreed to send me with them to 
India to earn money...next day I went to India with them, they took me to a big city, they kept me in a small room and went out. They never came back. Later another Nepali sister came and took me; she told me that I was sold.

\section{Traffickers}

A variety of people are involved in sex trafficking young women and girls. Sex trafficked women in this study described their traffickers to be typically men aged in their 20 s to 30 s (dalals) and older women aged in their 30s to 40s (dalalis). They felt that these people had travelled the routes before as they were familiar with local services and hotels in the destination cities. Most sex trafficked women/girls identified that traffickers worked in groups of two or more. Key informants identified that traffickers often had the patronage of the local authorities and gained protection through bribes to local police. Key informants also stated that although some traffickers worked independently, most were operating in a larger network which may involve carpet factory employers, brothel owners, government officials, border policemen and others. Traffickers may be working directly for a brothel or a carpet factory employer to recruit young women and girls.

The most common destinations for sex trafficking of the young women and girls in this study were Mumbai and Delhi. Table 3 shows that $44 \%$ of traffickers were persons familiar to the trafficked women and girls; these were often known, trusted members of their community or acquaintances. The women and girls who had been sex trafficked by familiar persons identified that job offers and to a lesser extent marriage offers led them into the sex trafficking process. One third of women were sex trafficked by persons who were unknown to them prior to the trafficking. These strangers are most likely to deceive women and girls with offers of employment; sex trafficking by force is also most likely to be conducted by persons unknown to the women/girls. It is significant to note that $22 \%$ of women and girls identified that a relative was involved their sex trafficking. These women/girls were most likely to be sex trafficked through offers of marriage or false visits. In most cases relatives included 
uncles, aunts, cousins, brothers or stepfathers who act as dalals. In addition, some traffickers are women who are involved in sex work in India themselves, often former sex trafficked women or sex workers who are now brothel managers or owners. These women may return to the village to participate in local festivals and travel through neighbouring villages to recruit young women and girls to the cities. These women are referred to as didi or phupu didi

(literally, paternal aunt) or sathi (best friend). An example of this process is shown below.

After two years of my marriage, my husband brought a sauta (a co wife) who gave birth to a son and I was then completely rejected from them. In the mean time, one woman who had come home for vacation promised me and my 3 other friends good jobs in Calcutta. We ran away with her and she took us to Calcutta. But instead of giving good job she sold three of us to different brothels.

\section{Life in Brothels}

The sex trafficked women/girls and key informants were asked about various aspects of work in Indian brothels. Key informants stated that Nepali women are often working in Indian brothels segregated from other brothels within the sex districts of large cities; these segregated areas are commonly referred to as Nepali kothas or compounds. The concentration of Nepali sex workers is thought to be highest in the Mumbai neighbourhood of Kamathipura where certain lanes are referred to as Nepali gallis (streets). Key informants stated that Nepali women are in particular demand as sex workers in India, and are often specifically requested by clients due to their attractive and youthful appearance and their supposed compliance in higher risk sex acts than Indian sex workers. Key informants identified three distinct types of Indian brothels; 'pillow houses', ‘bungalows' and 'call girls'; as described by a social worker below;

There are several grades of sex workers based on beauty, hard work and "talent".

The top is a 'call girl', then comes 'bungalow' which is a higher grade of regular brothel, then comes the 'pillow house' which is the lowest. Most girls start out in a 
pillow house and work up if they do well......some girls receive training, how to approach customers, language. During training girls are beaten and locked in a room like a jail...until they stop fighting. At first a girl gets two or three clients a day and then it escalates....

Sex trafficked women and girls often recalled their naivety upon arrival in the brothel districts of India. For example;

When they brought me here it was in a taxi. I kept looking around, wondering what kind of work was going on in this area of this big city. Everywhere I looked I saw curtained doorways and rooms. Men would go and come through these curtained entrances. People on the street would be calling out "Two rupees...Two rupees." I asked the other Nepali women if these were offices, it seemed the logical explanation. In two days I knew everything and I cried.

When I entered the brothel I saw many girls who looked younger than twenty years of age. I did not know what they were supposed to do. They looked very strange to me. I had never seen girls wearing so much make-up and bright red lipstick. Their clothes were different too. They all had on very short skirts with lots of jewellery. They were not typical Nepali girls. The brothel-keeper told me to take a bath, get make-up and put on some clean clothes. "What is my job?" I asked. "Why am I here? What's going on? I want to go home." "You will do what I tell you," said the brothel-keeper. "You will find out in a few hours." "I don't want to stay here," I replied more forcefully. "Let me go now. I don't want to stay here." But the brothelkeeper just laughed and walked away. I looked at the other girls for help." There's no way out," they said. "You're going to be working as a prostitute."

Sex trafficked women and girls reported that they were continually intimidated by brothel owners to work and pay off their 'debt', which is said to be the amount paid by the brothel owner to the trafficker. In addition to the purchase price, the 'debt' often included the cost of 
any medical expenses and protection money or bribes from police raids. Brothel owners repeatedly invoked a girl's indebtedness as a threat for compliance. Failure to comply with work often led to threats (of resale or report to authorities), beatings and psychological abuse. The trafficked women/girls stated that although they were forced to work, they earned no money for themselves until they had paid their 'debt' to the brothel owner. They stated that some brothels paid for food, clothes and medicine, however in most brothels these costs were added to their 'debt'. Most reported that they relied on tips from clients to purchase additional food or personal items, as shown below.

...all the women and girls where I worked were dependent on tips for food to supplement the meals provided by the brothel, but as a newcomer without regular customers, and an older woman at that, I got few tips...

We were never allowed out for fear we would run away. Everything was brought to the house, and shopkeepers charged very high prices... very expensive... bad quality...

After the 'debt' has been paid any earnings are supposedly divided between the brothel owner, local tax collectors and the woman/girl herself, however few women/girls experienced this division of earnings. Those who had been sex trafficked by relatives were also expected to use their earnings to support family in Nepal. A social worker interviewed in Nepal stated that male relatives may make periodic trips to India to collect a girl's earnings. If a village has several women in Bombay brothels, one community member may be appointed to travel to India to collect the money on behalf of family members. This meant that women and girls were not only under pressure to pay off their 'debt' but also to support family members through earning tips. An example of earnings of sex workers is shown below, to illustrate the lengthy period required to pay of their 'debt'. 
I worked in three low-grade brothels or 'pillow houses' and later in one fancier brothel commonly called a 'bungalow'. In the pillow house I had ten to twenty customers a day and, except for regulars, customers paid 25 rupees [50 cents] for five minutes. I also worked for four months in a bungalow which charged 100 to 300 rupees [US\$2-6] per hour. Some customers would pay to take the girls out all night, or sometimes for days at a time. If they were taken out to a hotel they paid at least 1,000 rupees [US\$20].

\section{Process of Exit from Sex Trafficking}

Three modes of exit from sex trafficking were identified by the women and girls in this study; rescue, escape or release. These exit routes are shown on the conceptual framework in Figure 2. The most common exit from sex trafficking reported in this study was 'rescue' after police raids for underage sex workers (those aged below 18 years). Data from the rehabilitation centres in Nepal show that $80 \%$ of women and girls left Indian brothels after being rescued (Table 4). However, this high figure may simply reflect the situation that rescued women/girls often pass through a rehabilitation centre. Typically these young women and girls were taken from the Indian brothels by social workers and/or the police and placed in an Indian transit home or rehabilitation centre before being transferred to a rehabilitation centre in Nepal. The following extracts highlight the rescue experiences of sex trafficked women and girls from brothels in India.

...Twelve days later the Indian Police raided the brothel. I was rescued and taken to a remand home in India where I stayed for five months and then brought back to Kathmandu...

One day a man (social worker) visited the place. Seeing how sad I was he asked me what was wrong. I told how I had been tricked into coming to this place and how I missed my young son and mother...He asked me for my address and said that he would write a letter to my family. God must have been happy with me because he sent that 
kind man to help me. He bought me home to Nepal and I am now back with my mother and son.

Even though the brothel owner told her to say she was twenty-one and had been working for two years, she told police... "I am not yet eighteen years old, I am being forced to work here against my will," I said. This worked and the police took me away from the brothel.

The second mode of exit from sex trafficking was escape from the Indian brothels. Although many women and girls reported failed attempts to escape from Indian brothels, $11 \%$ of women/girls reported a successful escape as their means of exit from sex trafficking. Escape from the brothel is much more likely amongst those who have been in the brothel for less than 12 months (Table 5). Examples of escape are shown below.

I tried to run away from the brothel many times but my attempts were always unsuccessful. There were always guards working for the brothel-keeper who could catch me. When they caught me they would throw me to the ground and beat me with sticks and pulled my hair.

I had one regular customer who was always very kind to me...He helped me to escape from the brothel and took me to live in his house which he shared with his brother. I stayed with them for three months but unfortunately his brother did not like me being there because of my background....and as we were not married...so he took me to a shelter for destitute women in Bombay. Then, I was eventually brought back to Nepal.

The brothel where I worked had a window so that all the girls could be observed by the management. When I was seen trying to escape, I was beaten. Whenever there was a police raid the owner would hide all the girls; those who tried to come out would be beaten. 
In fewer cases (7\%) women and girls left the Indian brothels after being released by the brothel owner. In general, women and girls were only released when the brothel owner felt that they no longer attracted sufficient clients or when they are tested as HIV positive. Table 5 shows that release by brothel owners is more common after five years at the brothel. In some cases women and girls are permitted to leave the brothel for a visit to family in Nepal and then never return.

In addition, some sex trafficked women and girls reported that they exited Indian brothels independently and did not pass through a transit home in India or a rehabilitation centre in Nepal. These women and girls either lived in India for some time or returned directly to Nepal. Some also returned to brothels in India after an independent return to Nepal, these were often sex trafficked women who had become brothel managers themselves. It was not possible to identify those who remained in India after exiting the brothel; however trafficked women and girls reported that these women sometimes marry in India or continue with sex work independently.

\section{Returning to the Community}

Most of the sex trafficked women and girls in this study spent some time in a rehabilitation centre in Nepal after exiting brothels in India. Rehabilitation centres are typically run by NGOs and provide health and social assistance to sex trafficked women and girls returned to

Nepal. In addition, women and girls are provided with literacy and skill building classes to assist them to integrate back into their communities. The majority (83\%) of sex trafficked women and girls spent less than 12 months in a rehabilitation centre; half of the women/girls spent less than six months in these centres. A smaller number stay in rehabilitation homes indefinitely after family rejection or difficulties in returning to the community. 
The experiences of sex trafficked women and girls who have left a rehabilitation centre and attempted to reintegrate into the community are of particular interest; twelve of these women and girls were interviewed in this study. Most had passed through a rehabilitation centre in Nepal, although four had returned to Nepal independently. These women and girls reported enormous problems in returning to community life. In particular, they reported a high level of social stigma directed at trafficked women and girls due to their involvement in sex work. Cultural norms in Nepal value a girl's virginity at marriage and sex trafficked women and girls are seen as spoilt, even though they may have been forced into this situation. A common phrase cited by a number of key informants captured the social values surrounding women and girls involved in sex work: "Ke garne chori cheli dimma jastai hunchha, ekchoti futepachhi, futyo, futyo." [What to do? Unmarried women/girls are like eggs, once broken they never rejoin, you cannot join them]. Another key informant expanded on societal views of sex trafficked women;

Society does not easily accept the return of trafficked women involved in prostitution. It means that sex can be a profession. It is highly immoral, it is inhumane rather. If you can rehabilitate them into society, if people are willing to take them as wives - this is meaningful rehabilitation.

Sex trafficked women and girls reported that some communities refuse to accept trafficked women. They stated that sex trafficked women and girls not only experience social stigma, but could also face rejection from their own families. Family rejection stemmed from the family's fear of social exclusion from the wider community as a result of their daughters 'shameful' behaviour. Sex trafficked women were also concerned about the impact of their return on the family reputation and the marriage chances their siblings, while others felt that their family may fear reprisals from the broker from whom they received money. In a number of cases women and girls themselves were unwilling to return to their family due to the fear of rejection or out of concern for the extra burden on their family if they returned ill. This was 
particularly true of those who had become HIV positive and therefore faced a double stigma resulting from their involvement in sex work and their HIV status. However, some key informants noted that if a sex trafficked woman returned home with money then she may be more easily accepted into the family and may be able to marry, while those who returned without money or were ill and unable to work were likely to experience rejection.

This research shows that once returned to the community, former sex trafficked women and girls typically become involved in three types of activities; marriage, small business or sex work in Nepal (see Figure 2). Half of the sex trafficked women who had returned to the community (6/12) resumed sex work in Nepal, regardless of whether they had passed through a rehabilitation centre. The most common reason given for returning to sex work was the need for financial independence as a result of family rejection and social stigma discussed above. These women and girls also stated they had few skills to seek alternative employment, and sex work was their only option. Others reported that their family had become dependent upon their income but were unaware of their involvement in sex work. The following extracts illustrate these reasons for returning to sex work.

When I was in Bombay, I used to send a little money to my family, but when I got TB, I was thrown out of the brothel and sent back to Nepal. I do this (sex work) because I don't have money and my family they have rejected me.

I send money home. Sometimes 1,500 rupees a month, sometimes 2,000. They have begun to build new house. My father believes that I am working in a cabin restaurant. I went home last year. I took clothes and some other presents for my sisters. They think I am successful... I would like to stop, but I cannot do anything else. Also, it's my habit now. 
Rehabilitation centres give us training but not a job, what to do with this one month training? Nobody will give us any job.

Secondly, sex trafficked women became involved in operating small businesses after leaving the rehabilitation centre. These women were all given seed money by the rehabilitation centres to establish small shops or stalls, which could generate independent incomes. Some of these women had returned to their natal families but had not married. Thirdly, a few (2/12) women had married, although this was the least common outcome of sex trafficking. One woman married with the assistance of the rehabilitation centre, which arranged the marriage ceremony; another had saved some money from sex work in India which made her attractive for marriage.

\section{Discussion}

A great deal of trafficking prevention work is currently being undertaken in Nepal, however, the context and process of sex trafficking remains unclear. Empirical research is critical in order to develop effective and targeted initiatives to reduce the phenomenon. This study provides a clearer understanding of the various stages of movement through the sex trafficking process of women who had contact with a rehabilitation centre. It highlights the complex nature of sex trafficking and the links between sex trafficking, other types of trafficking and migration of women in Nepal. It is clear that for the sex trafficked women in this study; anti-trafficking strategies need to adopt a range of activities at various levels to assist individuals at different stages of the sex trafficking process. Interventions need to be considered at; a) community level before movement has begun; b) urban centres which are both source and transitory centres for sex trafficking; c) trafficking level when women/girls are highly mobile and when they are in brothels; and d) return from sex trafficking as women and girls to move back into the community. The issues and interventions at each of these levels are highlighted below. 


\section{Community Initiatives}

Initiatives to reduce trafficking may be undertaken at the community level. These initiatives would largely focus on community education and awareness of sex trafficking to reduce the vulnerability of young women and girls to situations of entrapment and sex trafficking. The women and girls in this study are typically from a variety of ethnic groups, aged between 1318 years, have no education and both married and unmarried women are sex trafficked. This research also shows that sex trafficking is a more widespread geographic phenomenon than indicated in previous studies. Trafficked women and girls in this study originated from 37 districts of Nepal, particularly those bordering India and adjacent to Kathmandu. Previous work has identified sex trafficking exists predominantly in the Kathmandu Valley; while Government and NGO activities focus on only ' 19 danger districts' in which sex trafficking is thought to be prevalent (Pradhan 1996; Rajbhandari and Rajbhandari 1997; Ghimire 1998; Frederick and Kelley 2000). One of the major limitations of previous work is that the districts considered as source areas for all types of trafficking are identified informally rather than through analysis of existing data on trafficked women. This research therefore highlights that sex trafficking affects a wider group of women and girls than suggested in previous literature and there is a need to broaden the perception of those individuals and districts most affected by sex trafficking when designing intervention strategies.

One of the key findings of this research is that trafficking was most often conducted by familiar persons, including relatives; and that force and abduction are less common. Sixty eight percent of young women in this study were trafficked by a relative or familiar community member, thus there is considerably more familial involvement in sex trafficking than previously identified in Nepal. This research highlights a range of complex issues surrounding the involvement of family members in the sex trafficking process. In some instances family poverty led to parents naively endorsing their daughter's employment through a dalal, while for others a relative was central to the trafficking process. There is 
some suggestion of a power differential between impoverished families and brokers; whereby families fear reprisals from brokers if their daughter returned after rescue or escape from a brothel. The evidence of remittances sent to families in Nepal by some sex trafficked women may be reflective of cultural practices in certain communities in Nepal, such as the Badi, who endorse their daughters to undertake sex work as a means to support the family. This may also help to explain why some trafficked women were more easily accepted back into their home community if they returned with money. The nature and extent of familial involvement in the trafficking process remains unclear. Further in-depth research is required to understand these issues fully and identify the appropriateness of interventions.

This research has also identified that sex trafficking does not always begin at the village level; sex trafficking may also occur after migration to urban areas or it may occur after young women have been trafficked for other purposes, such as labour exploitation. These findings are not reflected in current information, education and communication (IEC) materials about sex trafficking used for community awareness. Much existing IEC material is developed on the premise that the families of sex trafficked women are passive innocents, and that women and girls are sex trafficked through direct routes such as kidnap and coercion (Asia Foundation and Population Council 2001). IEC material does not engage with the process of sex trafficking, which may begin with offers of domestic or factory employment and end in sex trafficking, and therefore is unable to increase community awareness about the full range of situations of entrapment for young women to sex trafficking. In addition, $80 \%$ of the sex trafficked women and girls in this is study had no education, yet existing IEC materials are in the form of leaflets and booklets targeted towards a literate audience.

There is an urgent need to review current educational materials on sex trafficking to have greater impact at the community level. Educational materials need to clearly convey the range of vulnerable situations which may lead to sex trafficking, in particular how sex trafficking may be interlinked with migration and trafficking for bonded labour. The involvement of 
familiar persons in trafficking also needs to be made more prominent, perhaps through personal testimonies of trafficked women. There is also a need to broaden the range of IEC materials into creative formats which do not rely on written materials. Such formats may include street theatre, community meetings and peer-led educational campaigns. Messages delivered through peers may be more realistic and relevant to young women and therefore have greater impact. Encouraging formerly sex trafficked women to share their experiences in community groups, schools or clubs may also sensitise the community to sex trafficking and help to reduce social stigma and discrimination towards trafficked women. It is also vital that community initiatives not only target individuals vulnerable to trafficking but also their parents, carers, village leaders and the wider community, so to raise the general awareness of the process of sex trafficking and situations of risk (Ghimire 2001). Holding community meetings for local government officials, medical personnel, law enforcers, teachers and social workers will also contribute to increasing community awareness and empowerment. Utilising the local and national media will not only raise awareness of sex trafficking amongst the community, but can play an important advocacy role in sensitising policymakers to the issues of sex trafficking.

It is vital that community initiatives to prevent sex trafficking adopt a more supportive, empowering approach to urban migration of women. Some approaches by NGOs aim to discourage migration of women, however, the increase in migration of women to urban areas for employment can have considerable economic benefits for the women involved and their families, therefore initiatives which attempt to reduce sex trafficking by discouraging such migration are likely to be ineffective (Walkowitz 1980; Brandt 1988; Asia Foundation and Population Council 2001). The forces of poverty which drive urban migration are likely to continue; therefore there is a compelling need for interventions that empower women in migration rather than seeking to protect women or discourage such movement. More sustainable community initiatives need to focus on strategies for safe migration by increasing women's awareness about the risks of urban migration, including increased vulnerability to 
sex trafficking (GAATW 1999). Strategies to facilitate safe migration may involve

encouraging women to discuss employment opportunities with others, seek accompaniment to the urban areas, leave details of the employer and workplace with community members. At the community level strategies may involve establishing employment agencies, developing links with urban employers or social agencies to provide support for women migrants. Additional strategies may include, informing migrating women about workplace conditions and sources of support such as women's networks in urban areas. Longer term community initiatives to reduce sex trafficking, and other types of trafficking (ie: bonded labour), would need to address the push factors which lead women into vulnerable situations to traffickers, such as the social and economic disadvantage of women in their home communities. Such initiatives may include women's leadership training, literacy and education programmes, micro credit schemes and training in livelihood skills (Huntington 2002). A combination of safe migration and rural development strategies is likely the most effective approach.

\section{Urban Initiatives}

It is clear from this research that sex trafficking may be conducted after women are first trafficking for labour exploitation to urban carpet factories or after women have migrated independently to work in carpet factories. Carpet factories, in particular, are a key focal point for sex traffickers as they represent a both a transit centre and a place where young women are particularly vulnerable to exploitation by sex traffickers. A clear gap in current trafficking awareness campaigns is the focus only on rural areas; this means that those who have migrated to urban area and those who have been trafficked for employment to urban areas remain unaware of the risks of sex trafficking from urban centres, most notably from carpet factories. What is required is a programme of community education and empowerment initiatives which focuses on both rural and urban areas. Previous research has also identified experiences of sexual coercion and abuse of young women employed in carpet factories (Puri et al 2003). Workplace interventions need to be given greater focus in trafficking awareness campaigns. This may involve establishing a programme of intervention at the factories 
themselves, which may utilise peer educators to create awareness of sexual abuse and the nature of sex trafficking from factories; developing support groups; or identifying a network of trusted confidants from whom to seek assistance. Such strategies in urban areas will enable both human and financial resources to be effectively targeted towards empowering those who are shown to be most vulnerable to sex trafficking from urban areas.

\section{Interception and Rescue Initiatives}

Once trafficking movement has begun trafficking intervention activities become more complex and involve either; a) interception during the sex trafficking process or b) rescue and repatriation from Indian brothels. Intercepting sex trafficked women and girls while in transit is a particularly difficult activity to manage without restricting valid migration and is closely tied to effective border management (Salt and Hogarth 2000). Huntington (2002) suggests that interventions during the transit stage of trafficking predominantly involve training and resources for border agents and local law enforcement officials. However, there remain difficulties in clearly identifying a sex trafficking case, and those being sex trafficked may also not be aware of the deception surrounding their movement (Huntington 2002). The open border between Nepal and India makes border management activities difficult.

Once sex trafficking movement has ceased, rescue and repatriation from the Indian brothels is the most appropriate intervention. These activities are not straightforward and involve close co-operation between authorities in India and Nepal. This research highlights that Nepali sex workers are concentrated in specific districts or brothels in the sex districts of large cities, which means that rescue initiatives can be effectively targeted. Police raids on Indian brothels remain an important strategy for identification of underage sex-trafficked women, however, these rescue and repatriation strategies need to consider that some women working in Indian brothels may not need rescue and view their employment as a valid means to support family in Nepal. 


\section{Initiatives for Integration or Independence}

Interventions at the post-movement phase of sex trafficking involve assisting sex trafficked women to return back into the community in Nepal. This research shows that support for trafficked women cannot be automatically equated with a return to their family or community of origin, although this remains a primary aim of NGOs in the care and support of trafficked women. Serious issues of social stigma in re-integrating sex trafficked women into the community were raised in this study and therefore reintegration is, in some circumstances, neither possible nor desirable. Therefore, community re-integration initiatives need to adopt a two-pronged approach. First, rehabilitation centres need to assist those able to return to their communities by; providing temporary residential care; health assistance; counselling, family assessment and follow up; and supporting empowerment activities such as providing skills training, literacy classes or seed money for establishing market stalls. Second, rehabilitation centres need to provide more effective skills for long term sustainable livelihood to women and girls who are unable or unwilling to return to their home communities. Such support may include training in marketable skills and business development, assistance with employment seeking and independent living. The current situation shows a lack of resources, expertise and co-ordination. This research has shown that without viable economic alternatives, sex trafficked women unable to return to their communities of origin will return to sex work and face continued stigma and social exclusion.

\section{Conclusion}

Kelley and Lee (1999) state that there exists no effective intervention model to prevent trafficking, partly because there exists no suitable framework of trafficking from which to develop effective interventions. Past initiatives have therefore adopted a welfare approach towards meeting the needs of trafficked women; however, such initiatives alone are inadequate as they ignore the importance of empowerment in the migration process and skill development in community re-integration. The conceptual framework developed in this study 
provides a clearer understanding of the process of sex trafficking amongst those who pass through a rehabilitation centre, and highlights the need for a range of interventions at various levels which reflect these stages of movement. At the community level, more relevant, realistic IEC materials are required to empower women to the risks of sex trafficking, together with strategies to foster safe migration. An expansion of awareness raising activities towards urban carpet factories is particularly critical. During the transit phase, interception and rescue activities are required; while at the post-trafficking stage activities focusing on community reintegration are needed together with initiatives to foster social independence for those unable to return to their home communities. In addition, stronger political commitment in allocating sufficient resources towards implementation and enforcement of anti-trafficking policies remains critical.

NOTE: All names in quotations are fictitious to preserve respondents' anonymity.

\section{Acknowledgements}

The fieldwork for this study was enabled through a Small Grant (No.02-0900) from the UK Department for International Development Knowledge Programme, Opportunities and Choices, based at the University of Southampton. The authors would also like to acknowledge the valuable support and co-operation of the NGOs in Nepal who provided access to data and assisted with respondent recruitment. 
Table 1 Socio-Demographic Characteristics of Sex Trafficked Women and Girls

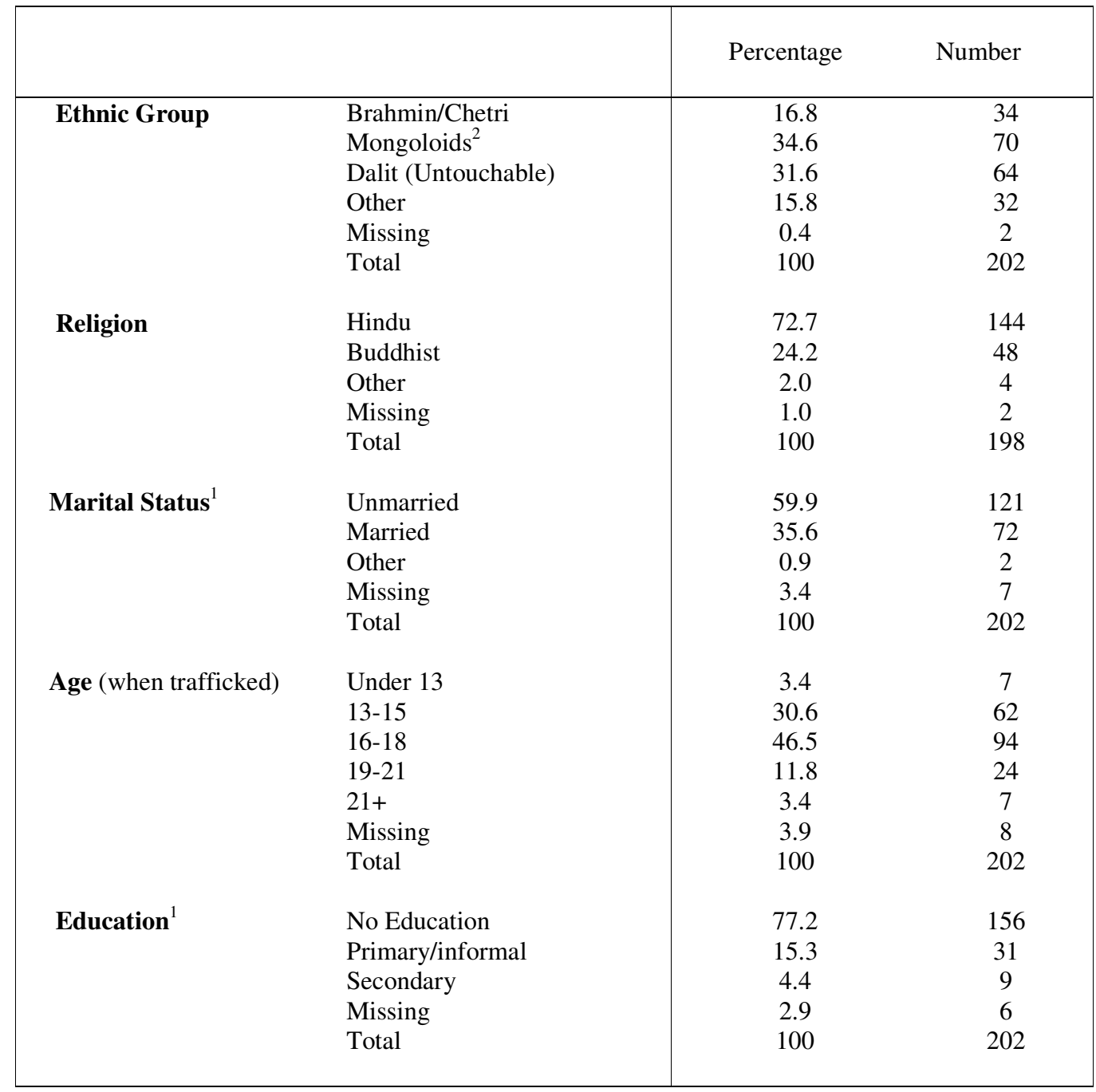

Note: Data from case records of sex trafficked women at all six rehabilitation centres in Nepal 19962001. ${ }^{1}$ At the time of sex trafficking. ${ }^{2}$ Includes Gurung, Magar, Rai and Tamang ethnic groups. 
Table 2 Routes into Sex Trafficking.

\begin{tabular}{|l|cc|}
\hline & Percentage & Number \\
\hline Employment-induced Migration through Dalal (Broker) & 59.4 & 120 \\
Fraudulent Marriage & 12.3 & 25 \\
False Visits & 16.3 & 33 \\
Force (abduction) & 6.4 & 13 \\
Missing & 5.4 & 11 \\
Total & 100 & 202 \\
\hline
\end{tabular}

Note: Data from case records of sex trafficked women at all six rehabilitation centres in Nepal 19962001. 
Table 3 Types of Traffickers.

\begin{tabular}{|c|c|c|c|}
\hline & & Percentage & Number \\
\hline Trafficker & $\begin{array}{l}\text { Relative } \\
\text { Familiar Person } \\
\text { Stranger } \\
\text { Missing } \\
\text { Total }\end{array}$ & $\begin{array}{c}21.7 \\
44.0 \\
30.1 \\
3.9 \\
100\end{array}$ & $\begin{array}{c}44 \\
89 \\
61 \\
8 \\
202\end{array}$ \\
\hline
\end{tabular}

Note: Data from case records of sex trafficked women at all six rehabilitation centres in Nepal 19962001. 
Table 4 Mode of Exit from Indian Brothel.

\begin{tabular}{|lcc|}
\hline & Percentage & Number \\
\hline Rescued & 73.7 & 149 \\
Escaped & 10.8 & 22 \\
Released by owner & 6.9 & 14 \\
Missing & 8.4 & 17 \\
Total & 100 & 202 \\
\hline
\end{tabular}

Note: Data from case records of sex trafficked women at all six rehabilitation centres in Nepal 1996-2001 
Table 5 Duration in Brothels by Mode of Exit $(n=184)$

\begin{tabular}{|l|cc|cc|cc|}
\hline \multirow{2}{*}{$\begin{array}{c}\text { Duration in Brothel } \\
\text { (months) }\end{array}$} & \multicolumn{7}{|c|}{ Mode of Exit from Brothel } \\
\cline { 2 - 7 } & \multicolumn{2}{|c|}{ Rescued } & \multicolumn{2}{c|}{ Escaped } & \multicolumn{2}{c|}{ Released by Owner } \\
$\%$ & No. \\
\hline Less than 12 & 27.5 & 41 & 54.5 & 12 & 0 & 0 \\
$12-36$ & 44.3 & 66 & 18.2 & 4 & 15.4 & 2 \\
$37-60$ & 18.8 & 28 & 22.7 & 5 & 38.5 & 5 \\
More than 60 & 9.4 & 14 & 4.5 & 1 & 46.2 & 6 \\
Total & 100 & 149 & 100 & 22 & 100 & 13 \\
& & & & & & \\
\end{tabular}

Note: Data from case records of sex trafficked women at all six rehabilitation centres in Nepal 19962001 
Figure 1 : District of Origin of Sex Trafficked Women at Rehabilitation Centres

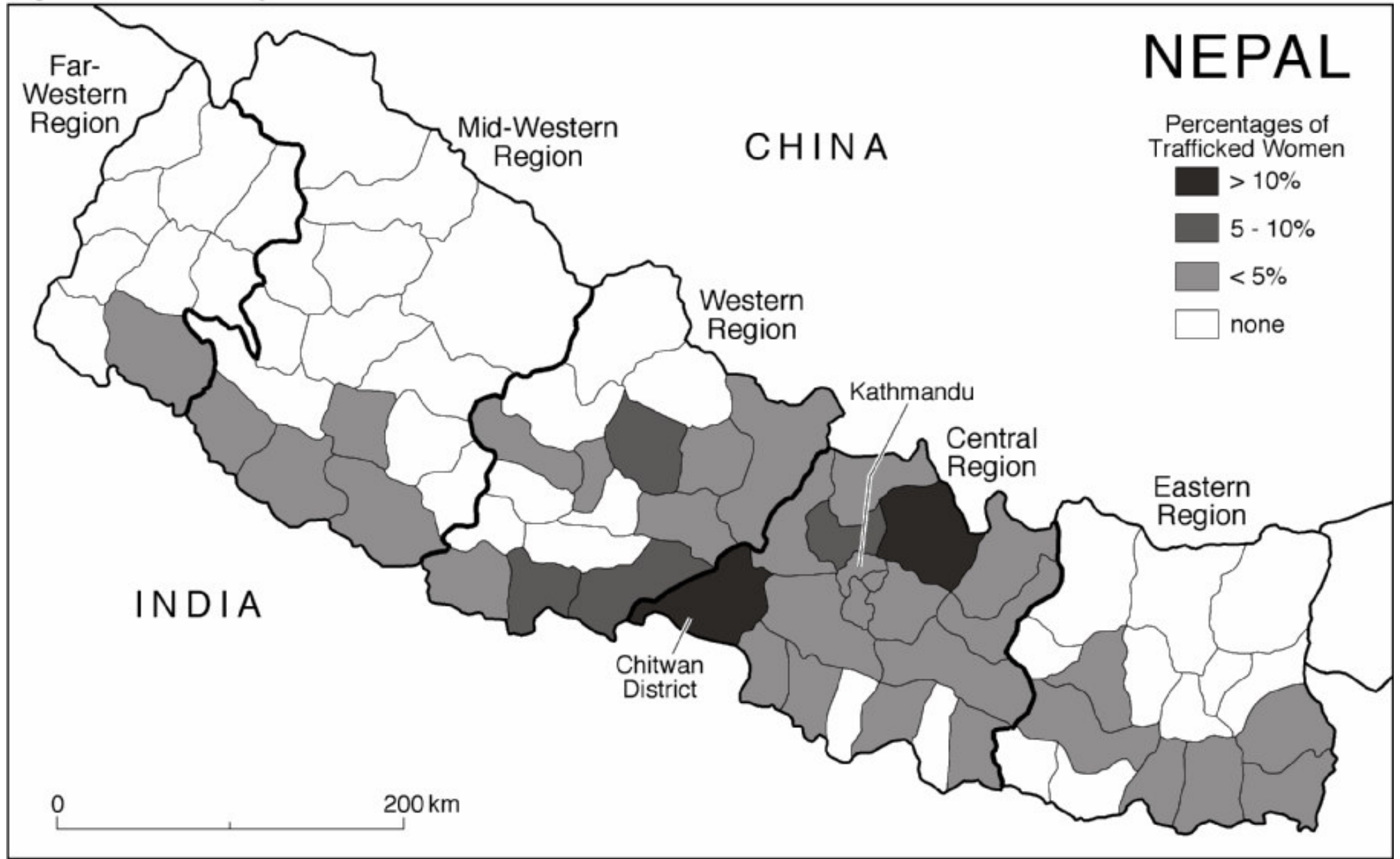

Note : data from case records of rehabilitation centres in Kathmandu 
Figure 2: Conceptual Framework of Entry and Exit to Sex Trafficking.

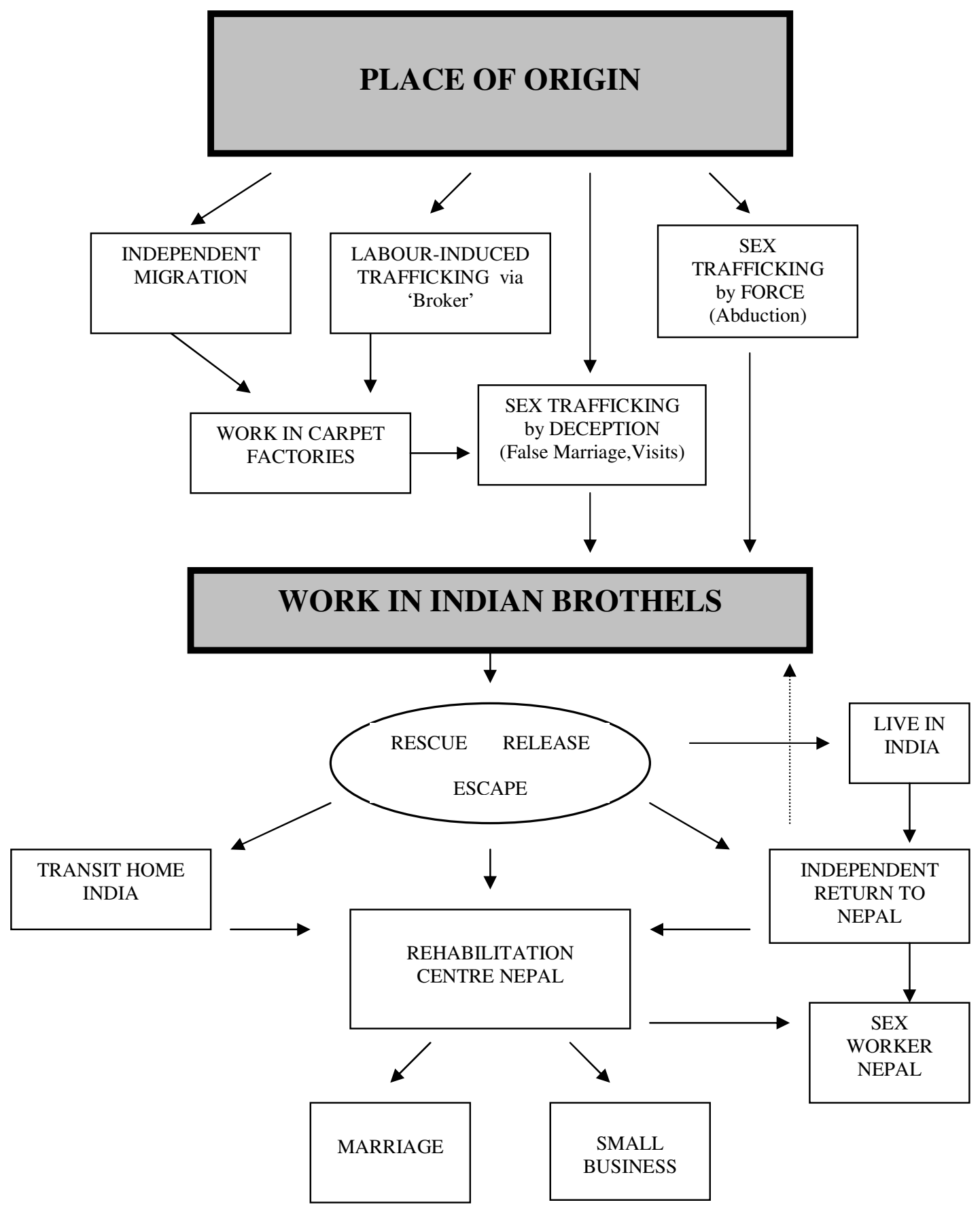




\section{References}

\section{ABC Nepal}

1996 Red Light Traffic: The Trade in Nepali Girls. ABC Nepal, Kathmandu

\section{ABC Nepal}

1998 Life in Hell: The True Stories of Girls Rescued from Indian Brothels. ABC Nepal, Kathmandu.

Acharya, U.

1998 Trafficking in Children and the Exploitation in Prostitution and other Intolerable Forms of Child Labour in Nepal: Nepal Country Report (unpublished) Prepared for ILO-IPEC. Kathmandu, Nepal.

Acharya, M., and Bennett, L.

1981 The Rural Women of Nepal: An Aggregate Analysis and Summary of 8 Village Studies. CEDA, Tribhuvan University: Kathmandu Nepal.

Asia Foundation and Population Council.

2001 Prevention of Trafficking and the Care and Support of Trafficked Persons: In the Context of an Emerging HIV/AIDS Epidemic in Nepal. The Asia Foundation and Horizons Project Population Council. Creative Press, Kathmandu Nepal.

Benner, $\mathrm{P}$.

1985 Quality of life: A phenomenological perspective on explanation, prediction, and understanding in nursing science. Advances in Nursing Science, vol. 8 (1), pp1-14.

Brandt, A.

1988 AIDS: From Social History to Social Policy. In Fee, E. and Fox D. (eds.) AIDS: the Burdens of History, pp.147-172, Berkeley: University of California Press.

\section{CeLRRd.}

2000 "Condemned to Exploitation: Impact and Corruption in Criminal Justice System on Women" Centre for Legal Research and Resource Development, Kathmandu, Nepal.

De Haan, A.

2000 Migrants, Livelihoods and Rights: The Relevance of Migration in Development Policies. Social Development Working Paper No. 4. Poverty Research Unit, University of Sussex.

Frederick, J., and Kelly, T. (eds.)

2000 Fallen Angels: The Sex Workers of South Asia, New Delhi; Lustre Press, Roli Books.

\section{GAATW.}

1999 The Migrating Women's Handbook. Bangkok. 
Ghimire, D.

1998 Chelibetiko Abaidh Vyapar (Illegal trade of girls) in Ghimire,D.(ed.). Chelibetiko Abaidh Vyapar: Yasaka Vivid Paksha (Illegal trade of girls: Its various aspects), pp116. ABC Nepal, Kathmandu.

Ghimire, D.

2001 Prevention, care, rehabilitation and reintegration of rescued girls ( $A B C$ 's Experience) Paper presented at the Technical Consultative Meeting on Anti-trafficking Programmes in South Asia, September 2001.

Gushulak , B., and MacPherson D.

2000 Health Issues Associated with the Smuggling and Trafficking of Migrants. Journal of Immigrant Health, Vol. 2 No. 2:67-78.

HMG Nepal.

1990 The Constitution of the Kingdom of Nepal 2047 (1990). His Majesty's Government Ministry of Law, Justice \& Parliamentary Affairs, Kathmandu Nepal.

Human Rights Watch.

1995 Rape for Profit: Trafficking of Nepali Girls and Women to Indian Brothels. Human Rights Watch, New York, USA.

Huntington, D.

2002. Anti-Trafficking Program in South Asia: Appropriate Activities, Indicators and Evaluation Methodologies; Summary Report of a Technical Consultative Meeting. Population Council, New Delhi.

\section{ILO/IPEC}

1998 Trafficking in Children for Labour Exploitation, including Sexual Exploitation in South Asia: Synthesis Paper (unpublished). Nepal South Asia Sub-Regional Consultation.

Kelly, P. and Lee, B.

1999 Children and women trafficking in Vietnam: what we know from literature, interviews, and analyses. Ha Noi.

Khatri, N.

2002 Nepal: The Problems of Trafficking in Women and Children. A Paper Presented at the $7^{\text {th }}$ Annual Meeting of the Asia Pacific Forum for National Human Rights Institutions. November 11-13 New Delhi, India.

Leininger, $\mathrm{M}$.

1985 Qualitative Research Methods in Nursing. Grune \& Stratton Inc., New York. 
Leone T, Matthews Z and Dalla Zuanna G.

2003 Impact and Determinants of Gender Preference for Children in Nepal. International Family Planning Perspectives 29: 69-75.

Ministry of Health (Nepal), New Era and ORC Macro.

2002 Nepal Demographic and Health Survey 2001. Calverton Maryland, USA: Family Health Division, Ministry of Health; New Era; and ORC Macro.

O'Dea, P.

1993 Gender Exploitation and Violence: The Market in Women, Girls and Sex in Nepal: An Overview of the Situation and a Review of the Literature. Kathmandu: UNICEF.

Poudyal P.

1996 Report of the South Asian Workshop on Trafficking in Women and Children. Gender and Development, Vol.8 p 74-79.

Poudel and Carryer.

2000 Girl-Trafficking, HIV/AIDS and the Position of Women in Nepal. Gender and Development. Vol 8:74-79.

Pradhan, G.

1996 Back Home from the Brothels: A Case Study of the Victims of Commercial Sexual Exploitation and Trafficking Across Nepal-India Border. Kathmandu: CWIN.

Puri, M., Cleland, J. and Matthews, Z.

2003. Extent of Sexual Coercion among Young Female Migrant Workers and their Sexual Health Problems in Nepal. Paper presented at the Annual meeting of the Population Association of America, 1-3 May 2003, Hilton Minneapolis \& Towers, Minneapolis, USA.

Rajbhandari, R. and Rajbhandari, B.

1997 Girl Trafficking: Hidden Grief in the Himalayas, WOREC, Kathmandu, Nepal.

RIDA

1991 The Status of the Girl Child in Nepal: a survey report. Prepared for HMG/MDL and UNICEF Nepal.

Rozario, S. and Rita, M.

1988 Status of Women Series: Trafficking of Women and Children in India (Sexual Exploitation and Sale). New Delhi, India. 
Salt, J and Hogarth, J.

2000 Border Control. Chapter 9 in Laczko F, and Thompson D (eds) Migrant Trafficking and Human Smuggling in Europe, IOM, Geneva.

Sanghera, J.

2000 Trafficking of Women and Children in South Asia: Taking Stock and Moving Ahead (unpublished), report prepared for UNICEF Regional Office South Asia and Save the Children Alliance South and Central Asia.

Shtrishakti

1995. Women Development and Democracy. A study of the Socio-Economic Changes in the Status of Women in Nepal 1981-1993. Kathmandu Nepal.

Seddon, S., Jagganayth, J., and Gurung, G.

1999 Foreign Labour Migration and the Remittance Economy of Nepal (unpublished) Report prepared for DFID Nepal Country Office.

Taylor and Bogdan.

1984 Taylor, S. J. and Bogdan, R. (1984). Introduction to Qualitative Research Methods: The search for meanings. New York: John Wiley \& Sons

United Nations.

2000 Protocol to Prevent, Suppress and Punish Trafficking in Persons, Especially Women and Children. Supplementing the UN Convention against Transnational Organized Crime, Annex II. United Nations Doc A/55/383.

United States Department of State.

2001 U.S. Department of State (2001) Victims of Trafficking and Violence Protection Act 2000: Trafficking in Persons Report, July 2001.

UNDP

1999 Beyond Trafficking: A Joint Initiative in the Millennium Against Trafficking in Women and Girls. Kathmandu, Nepal.

UNDP

2003. Human Development Report 2003. Millenium Development Goals. A Compact Among Nations to End Human Poverty. United Nations Development Programme, New York.

\section{UNFPA}

2000 State of the World's Population. UN Fund for Population Activities September 2000:5. 


\section{UNICEF}

1996 Children and Women of Nepal: A Situational Analysis. Kathmandu, Nepal.

Walkowitz, J.

1980 Prostitution and Victorian Society: Women, Class and the State. London: Cambridge University Press.

\section{WOREC/CEDPA.}

1999. Advocacy Against Trafficking in Women Training Manual, prepared by WOREC and CEDPA, Kathmandu, Nepal. 